\title{
Somerset's Case: The Unsung Verdict and Its Legacy
}

\author{
Sehoon Baek
}

Naperville North High School, Naperville, IL, USA

DOI: https://doi.org/10.47611/jsrhs.v10i2.1485

\section{$\underline{\text { ABSTRACT }}$}

The paper is a comparison between the English court case Somerset v. Stewart(1772) and the infamous American suit Scott v. Sandford(1857), both of which deal with the issue of a slave's freedom and seeks to analyze the reason why the judges overseeing these cases rendered different verdicts. The paper specifically explains the verdict of Somerset, which freed the slave in question, and Scott, which did not, in a socio-economic lens, pointing to the American dependency on slavery as a factor in the disenfranchisement of African-Americans, which was less of a factor in England that contributed to an early end to slavery in that country, including through the inclusion of black men in the Royal Army and Navy during Britain's conflicts with the United States of America. Although a misinterpretation of Somerset's Judge Lord Mansfield's verdict, a wide-spread, broad understanding of his decision led to the acceptance of legal freedom for slaves throughout Britain, reinforcing American attempts to resist runaway attempts of slaves for Britishcontrolled territory during the Revolutionary War and later the War of 1812. The paper finally renders the American Revolution as a hypocritical one that did not immediately contribute to equality, and notes Mansfield's overlooked role in the abolition of chattel slavery.

\section{Introduction}

In the 7,000 years since the first known human settlement of Eridu was founded in Mesopotamia, marking the beginning of human history, few men or women have left their mark on the books of which we now record their exploits. Even fewer helped to elevate them to these books yet could not have their journey written. While we honor the lives of individuals such as Abraham Lincoln, there are individuals that go less mentioned that helped propel those great men and women to such status. William Murray, 1st Earl of Mansfield, or the Lord Mansfield, was one of those, having set a precedent for others to break barriers set upon blacks in England. His landmark case, Somerset v. Stewart (1772), announced by him as the Chief Justice of the Court of King's Bench, declared lack of lawful support of chattel slavery in England, setting the stage for its complete removal in 1833. It would bear a profound contrast to its American equivalent, Dred Scott v. Sandford(1857). Indeed, through Mansfield's decision, the United Kingdom, despite the criticism towards the tyranny it exerted against America, was actually able to abolish slavery at least two decades earlier than the United States. The reason why abolition happened earlier in the UK and it took longer for the US can be found through the socio-economic landscapes of the two countries with starkly different verdicts on slavery.

\section{Methodology}

Most of the time spent on this paper was spent on gathering and using sources, which were mostly collected online and at the local public library. The sources for this paper were primarily hardcover research-based books, online news articles, and transcripts of primary sources covering various parts of the Somerset and Scott decisions, ranging from the Middle Passage and conditions aboard slave ships to the effects of each court case. Additional sources were the autobiography of a former slave, Olaudah Equiano, discussing his treatment, an article from the National Archives of 
the United Kingdom, statistics from a university in Utah detailing the number of slaves in the US in 1860, and a transcript of English higher court cases beginning in 1220 (of which Somerset was included).

\section{Somerset's Case}

By 1772 in the British Empire, slavery had been in practice for at least two centuries, beginning from the first slave trader, John Hawkins. British interests originally lay in African goods, with demands for labor in the colonies supplied by convict labor. However, with these demands often being unmet, England began to turn to African slave labor(UK National Archives). The Archives further estimates around 3.1 million slaves were transported from Africa, of which 2.7 million survived, to British colonies between 1640 and 1807. The transport of slaves from Africa to the colonies was regarded as an inhumane and cruel process, with cramped quarters and constant threat of diseases (Liverpool Museums). The tales of those such as Olaudah Equiano, a former slave himself who survived on a slave ship, helped raise awareness about these conditions, leading to the formation of the abolitionist movement.

Equiano wrote in his autobiography that during his journey from Africa, "I became so sick and low that I was not able to eat,"(Equiano 52), but that when this was discovered, his white overseers flogged him to the point where he, like many other chained slaves on the ship desired to drown themselves. Equiano described a fellow female slave getting silenced with a muzzle, akin to dog-like treatment. James Somerset, standing before the Lord Mansfield, was, like Equiano, a slave. He would have likely endured similar conditions.

So cruel was the treatment of the enslaved that the property of a Boston civil servant, Charles Stewart, James Somerset, escaped when brought to England in 1769, only to be recaptured and put on a ship to Jamaica in 1771. Somerset's allies in Britain, such as Granville Sharp, approached by Equiano ten years later over the slave ship Zong(Metaxas 103 106), brought Somerset before Lord Mansfield, the Lord Chief Justice. (Extraordinarily enough, Lord Mansfield would later preside over Sharp's legal filing against the Zong crew.) Mansfield narrowed down the central inquiry of the case Somerset $v$. Stewart to this: "if the owner had a right to detain a slave, for the sending of him over to be sold in Jamaica."(English Reports, Vol 98)

Somerset's lawyers argued no law provided any authorization of slavery in England even if that might be the case in her colonies. Stewart retorted that Somerset was still his property, and property took precedence over Somerset's freedom(New England Historical Society). While Lord Mansfield believed slavery was at least tolerated in England, his verdict revealed his dislike of slavery, though unlikely influenced by the fact that he had a black grand-niece whose status was ambiguous (Gerzina 96);

"[Slavery] is so odious, that nothing can be suffered to support it, but positive law. Whatever inconveniences, therefore, may follow from the decision, I cannot say this case is allowed or approved by the law of England; and therefore the man must be discharged."(English Reports, Vol 98)

In his verdict, Lord Mansfield noted Somerset had escaped and lived free, until he was taken and put back onto the ship against his consent to be sold. Mansfield first established that as a foreigner had to abide by English law, not his own, when he was in England, so should a slaveholder abide by English law and not colonial law. He had earlier recognized that the Tenures Abolition Act of 1660 by the English Parliament repealed serfdom, or feudalism in England(English Reports, Vol. 98), and implied that the act could apply given the nature of chattel slavery. Lord Mansfield declared that Somerset be released, supporting Somerset's argument that no law explicitly permitted slavery. British slavery would go on to be abolished in 1837, with a short apprenticeship system that transitioned the enslaved population to freedom ending in 1838 (Discovering Bristol).

To take a person on English soil against their will onto a ship bound for sale in a foreign nation being declared illegal meant that the whole concept of slavery was itself illegal in England. With the judgement, the abolitionists were even further galvanized, especially so when the slave ship Zong in 1781 had inhumanely thrown sick slaves overboard to increase profit(Metaxas 103 106). Besides, the Slave Trade Act of 1807 which once was ill-enforced, 
would eventually be strengthened to abolish the illegal trade(Hansard). England became known as the nation of black freedom, enticing African Americans in the colonies with knowledge of the verdict to attempt to make their way to Britain (Schneider, Schneider 56 57). By contrast, the slaves of America would continue to be traded within the US, with many who escaped heading to the northern free states, Canada or Mexico (Harriet Tubman Historical Society). Though the Founding Fathers tried to build up a democratic republic on the promise of freedom from an oppressive kingdom, that same kingdom was more democratic than the republic itself.

When America went to war with Britain in 1812, American commanders refused the service of black servicemen to defend Philadelphia - even after Washington, D.C. itself had been taken and burned to the ground. At the Battle of New Orleans, 600 blacks fought alongside Andrew Jackson under the promise of freedom that was soon rescinded (Horton 82). In comparison, British Vice Admiral Cochrane proclaimed that anyone who were to leave American territory and reach a British vessel or military base would have the option of joining the British military alongside whites and simultaneously be given the opportunity to live as free settlers in British America(Canada) or the Caribbean(Horton 292). Over 3,500 blacks obliged (Horton 81).

\section{Dred Scott's case in comparison to Somerset's}

Mansfield's Somerset verdict(and its effects) can be compared to a verdict that indeed debates whether the American republic, founded under the principle of the equal protection of the law, was truly equal given its criticism toward the immorality of Britain as asserted by the Founding Fathers. In 1857, a slave named Dred Scott went before the Supreme Court in a battle for his freedom. At the time, the US prohibited slavery in the states of Illinois, Wisconsin, and other numerous northern states, the first two of which Scott had lived in under his master (PBS). Living in Missouri at the time, he had gone before both state and federal courts to argue his case. In what was perhaps one of the most pivotal decisions on American slavery by the Supreme Court, the Court ruled not only against his freedom, but also against the provision of citizenship to free African Americans (thus denying Scott his ability to appear in court to begin with due to his state as a slave). In justification, the Court syllabus noted the history of the republic; at the time of the breakaway from Britain, the Court argued, the rights conferred to "people" by the Declaration of Independence and the Constitution were specifically intended to apply to whites only (Cornell Law School). This included the right of keeping one's property, which to the Court, clearly justified the status of African Americans as property which was to be kept. The Court ruled Scott as "lawful property".

The Court asserted that the very reason that allowed Scott to sue to begin with, the Missouri Compromise which prohibited slavery in any state north of the 36.5th parallel(except for Missouri), was a violation of federalism. The people of the states where slavery was banned, such as Illinois, Wisconsin, Maine, etc., had not decided by themselves to abolish slavery in their states(instead, their representatives far away in Congress had done so); therefore the Compromise could not stand as legal in the US. (Before this, the Kansas-Nebraska Act of 1854 was passed by Congress to allow settlers in the territories of Kansas and Nebraska, both being above the Missouri Compromise line, to determine their destiny as free or slave states[US Senate].)

Already there had existed tension in the US regarding slavery although Scott worsened it. Violence between pro-slavery and anti-slavery irregulars had existed in Kansas since the passage of the Kansas-Nebraska Act, continuing onto the Civil War. Known as "Bleeding Kansas", the conflict was considered to be a rehearsal or prelude to the Civil War. Proslavery settlers from Missouri swarmed Kansas to sway its decision on whether to be a free or slave state in response to the Act, in many cases through electoral fraud(American Battlefield Trust). The Scott ruling only further inflamed tensions, given that now slavery could not just be permitted in Kansas and Nebraska, but also in states that, should their people hold a referendum with different results, had previously prohibited slavery.

\section{The Socio-economic Explanation of the Different Verdicts}


Long in opposition to slavery before the Scott case(in 1764), James Otis, a lawyer in Massachusetts, argued that liberty was a God-given right to both blacks and whites. "The colonists, black and white, born here, are free born British subjects, and entitled to all the essential civil rights of such"(D. Schneider, C. Schneider 49), he said. However, the American economic dependency on slavery was simply too great to take action against it. According to the 1860 Census(Weber State University), the total number of slave owners in the US was 385,000, counting those in the Lower and Upper South, in addition to Civil-War border states. In comparison, an analysis of the Guardian in 2015 reveals that only 46,000 slave owners existed in Britain.

This numerical difference shall lead to understanding the divergence between Somerset and Scott, through the economic and political differences between Britain and the US. The US economy, especially the American South, was oriented around the cultivation of raw products, particularly cotton. British textile mills, even after the Revolutionary War and the War of 1812, still traded in American cotton, accounting for half of the entirety of annual cotton refined by these mills. Slave labor in the American South, including the newly purchased areas of the Louisiana Territory, became increasingly valuable for cotton production than any other export the nation had by 1840 . This commercial crop rose during the first two decades of the 19th century to account for $38 \%$ of US exports, and not long after, cotton's rise to the top of American exports also increased the political power of American Southern slaveholders (Horton 86).

The requirement of cheap, indentured labor to manually pick these products eventually led to the establishment of slavery in the US to meet demand early on whereas the UK primarily focused on refining those products. The UK did not require slave labor within its homeland territory in the sense that it required a different type of labor in refinement of raw goods, which was eventually and notoriously supplied by children, who accounted for $15 \%$ of the entire British workforce by the early 19th century (Keys 2010). Although there was slavery on both sides of the Atlantic, its real purpose was the triangular exchange between Britain, America, and Africa; Africa supplied labor, the Americas used that labor to develop raw products, and Britain used those products to create a refined good. The trade still continued in the US because of the increasing reliance on that economic method. In the UK, however, as it rose as the epicenter of the Industrial Revolution, there was less of a dependence on unskilled, agricultural laborers as there was in the US. The powerful in the UK had any incentive to restrain their slaves if they had any, whereas in the US, those who were in power or had stakes in such industries that employed slave labor felt it necessary so as to maintain their business model; even if it would split the nation apart. Those at stake of the UK saw no reason to retain slavery. For American slave owners, their struggle was about preserving wealth and the system that had allowed them to accumulate that wealth through war; they had far more to lose should slavery come to an end than did those in Britain.

\section{Conclusion}

The economic relationship between Britain and its colonies made it possible for the UK to rethink the institution of slavery and its benefits as it was not as economically dependent on the institution as was in the US. The British people and their industry were less reliant on slavery for their profits, and so began, as did Granville Sharp and the British military, to eventually regard slavery as an immoral institution worthy of abolition, to the point where it was declared unlawful by Lord Mansfield.

Somerset was the enabler of great men, empowered by the conditions of the time, their conviction, and courage to carry out the laws that saw to it that it was illegal, so that black people could truly be rendered equal. As Scott would continue its abridgement of the rights of blacks, it would take the blood of millions, including of a President, and an additional hundred years to finally end it in the US.

The decision by Lord Mansfield, the sole judge and deliverer of the Court of King's Bench, and its implications were truly the unsung verdict, often unremembered and forgotten in the history of slaves. While those such as William Wilberforce and Harriet Tubman are revered, their historical legacy could not have come about if Mansfield had not unlocked the door of the barriers of inequality and injustice first for them to knock it down. Had Mansfield 
not broken the barrier of enslavement and servitude, their cause might have all but sunk. Through his judgement, the road was paved for the emancipation and eventual equality of all.

\section{Acknowledgments}

I would like to thank my parents for supporting me while I worked on this paper independently out of school. I would also like to thank my history teacher Mr. Jeffry Bedore.

\section{References}

\section{Primary Sources}

David Keys. 2010. "Revealed: Industrial Revolution was powered by child slaves.” The Independent. August 2 , 2010. https://www.independent.co.uk/news/uk/home-news/revealed-industrial-revolution-was-powered-by-childslaves-2041227.html."

Equiano, Olaudah. "Chapter II.” In The Interesting Narrative of the Life of Olaudah Equiano, or Gustavus Vassa, the African, London: W.Cock, 1815

Somerset v Stewart (1772) 98 ER 499

\section{Secondary Sources}

“Apprenticeship: slavery by another name?” PortCitiesBristol, Accessed January 2, 2020

"Britain and the Slave Trade." National Archives, Accessed January 2, 2020

Gerzina, Gretchen. Black London: Life Before Emancipation. New Brunswick, NJ: Rutgers University Press, 1995.

James Oliver Horton, Lois E. Horton. “Slavery and the Making of America.” Accessed January 20, 2020

"James Somerset, the Boston Runaway Who Ended Slavery in England." New England Historical Society, Accessed January 2, 2020

"Life on board slave ships.” Liverpool Museums, Accessed January 2, 2020

Metaxas, Eric. Amazing Grace:William Wilberforce and the Heroic Campaign to end Slavery. New York: HarperCollins, 2007.

Olusoga, David. "The history of British slave ownership has been buried: now, its scale can be revealed." The Guardian, Accessed March 30, 2020

Schneider, Dorothy and Schneider, Carl J. "Slavery in America: From Colonial Times to the Civil War." Facts on File Library of American History, Accessed January 20, 2020

“Scott v. Sandford.” Cornell Law School Legal Information Institute, Accessed March 28, 2020 
"Selected Statistics on Slavery in the United States." Weber State University, Accessed March 30, 2020

“Slave Trade Felony Bill.” Hansard, March 5, 1811

“The Civil War: The Senate's History.” United States Senate. Accessed April 11, 2020.

"What was the Underground Railroad?" Harriet Tubman Historical Society, Accessed January 2, 2020 